\title{
Isolation and Identification of Sodium Fluoroacetate Degrading Bacteria from Caprine Rumen in Brazil
}

\author{
Expedito K. A. Camboim, ${ }^{1}$ Arthur P. Almeida, ${ }^{1}$ Michelle Z. Tadra-Sfeir, ${ }^{2}$ \\ Felício G. Junior, ${ }^{1}$ Paulo P. Andrade, ${ }^{3}$ Chris S. McSweeney, ${ }^{4}$ \\ Marcia A. Melo, ${ }^{1}$ and Franklin Riet-Correa ${ }^{1}$ \\ ${ }^{1}$ Unidade Acadêmica de Medicina Veterinária, Universidade Federal de Campina Grande, 58708 Patos, PB, Brazil \\ ${ }^{2}$ Laboratório de Fixação Biológica de Nitrogênio, Departamento de Bioquímica e Biologia Molecular, \\ Universidade Federal do Paraná, 80060 Curitiba, PR, Brazil \\ ${ }^{3}$ Departamento de Genética, Universidade Federal de Pernambuco, 50670 Recife, PE, Brazil \\ ${ }^{4}$ CSIRO Livestock Industries, Queensland Bioscience Precinct, St Lucia, QLD 4067, Australia \\ Correspondence should be addressed to Marcia A. Melo, marcia.melo@pq.cnpq.br
}

Received 1 April 2012; Accepted 7 May 2012

Academic Editors: T. Ledon, S. F. Porcella, and B. I. Yoon

Copyright ( 2012 Expedito K. A. Camboim et al. This is an open access article distributed under the Creative Commons Attribution License, which permits unrestricted use, distribution, and reproduction in any medium, provided the original work is properly cited.

\begin{abstract}
The objective of this paper was to report the isolation of two fluoroacetate degrading bacteria from the rumen of goats. The animals were adult goats, males, crossbred, with rumen fistula, fed with hay, and native pasture. The rumen fluid was obtained through the rumen fistula and immediately was inoculated $100 \mu \mathrm{L}$ in mineral medium added with $20 \mathrm{mmol} \mathrm{L}^{-1}$ sodium fluoroacetate $(\mathrm{SF})$, incubated at $39^{\circ} \mathrm{C}$ in an orbital shaker. Pseudomonas fluorescens (strain DSM 8341) was used as positive control for fluoroacetate dehalogenase activity. Two isolates were identified by $16 \mathrm{~S}$ rRNA gene sequencing as Pigmentiphaga kullae (ECPB08) and Ancylobacter dichloromethanicus (ECPB09). These bacteria degraded sodium fluoroacetate, releasing $20 \mathrm{mmol} \mathrm{L}^{-1}$ of fluoride ion after 32 hours of incubation in Brunner medium containing $20 \mathrm{mmol} \mathrm{L}^{-1}$ of SF. There are no previous reports of fluoroacetate dehalogenase activity for P. kullae and A. dichloromethanicus. Control measures to prevent plant intoxication, including use of fences, herbicides, or other methods of eliminating poisonous plants, have been unsuccessful to avoid poisoning by fluoroacetate containing plants in Brazil. In this way, $P$. kullae and A. dichloromethanicus may be used to colonize the rumen of susceptible animals to avoid intoxication by fluoroacetate containing plants.
\end{abstract}

\section{Introduction}

The most important group of poisonous plants in Brazil is one that causes "sudden death" during physical effort, responsible for nearly 500000 cattle deaths each year. It is composed of 13 species of plants, belonging to 3 families: Rubiaceae (Palicourea marcgravii, P. aeneofusca, P. juruana, and P. grandiflora); Bignoniaceae (Pseudocalymma elegans, Arrabidaea bilabiata, and A. japurensis); and Malpighiaceae (Mascagnia rigida, M. elegans, M. pubiflora, M. aff. rigida, M. exotropica, and M. sepium) [1-10]. P. marcgravii is the most important Brazilian toxic plant and $M$. rigida is the most important toxic plant in Northeastern Brazil [11]. Sodium fluoroacetate was identified as the active principle in P. marcgravii, A. bilabiata $[12,13]$, and M. rigida [14]. In the other plants the active principle has not been identified, but is probably also sodium fluoroacetate [15]; it disrupts the tricarboxylic acid cycle, being first converted to fluorocitrate, which in turn inhibits the enzymes aconitase and succinate dehydrogenase resulting in citrate accumulation in tissues and plasma, and ultimately causing energy deprivation, and death [16]. Microbial degradation of sodium fluoroacetate is catalyzed by a fluoroacetate dehalogenase, which cleaves the strong carbon-fluorine bond [17], but also cleaves, although less effectively, other bonds such as carbon-chlorine, carbonbromine and carbon-iodine [18]. Sodium fluoroacetate can also be defluorinated by L-2 haloacid dehalogenases [19].

Several soil bacteria have the ability to degrade sodium fluoroacetate. In central Australia, seven fluoroacetate 
degrading bacteria genera including Acinetobacter, Arthrobacter, Aureobacterium, Bacillus, Pseudomonas, Weeksella, and Streptomyces were isolated [20]. Recently, seven bacterial strains isolated from Brazilian soil samples have been described, belonging to the genera Ancylobacter, Burkholderia, Cupriavidus, Paenibacillus, Staphylococcus, Stenotrophomonas, and Ralstonia [21]. However, a single ruminal bacterial isolate, belonging to the phylum Synergistetes, was reported as being able to degrade sodium fluoroacetate $[22,23]$. As the result of our attempt to ascertain whether naturally-occurring fluoroacetate-degrading microorganisms exist in the gastrointestinal systems of animals, we report here the isolation of two new fluoroacetate degrading bacteria from goat rumen.

\section{Material and Methods}

2.1. Collection and Samples Processing. The animals were male adult goats, crossbred, with rumen fistula, and fed with hay, native pasture, and water ad libitum. They were housed in the Veterinary Hospital of the Universidade Federal de Campina Grande in the State of Paraíba, Northeastern Brazil, and had no access to areas with sodium fluoroacetatecontaining toxic plants.

The rumen fluid was obtained through the rumen fistula and immediately inoculated in test tubes.

2.2. Bacterial Isolation. Bacterial isolation started by the inoculation of $100 \mu \mathrm{L}$ of rumen fluid in tubes containing $9 \mathrm{~mL}$ of mineral medium (Brunner) added with vitamins (http://www.dsmz.de/microorganisms/medium/pdf/DSMZ_ Medium457.pdf) and $20 \mathrm{mmol} \mathrm{L}^{-1}$ sodium fluoroacetate (SF) (Sigma-Fluka) as single carbon source. This medium will be here designated as Brunner medium. Samples were incubated at $39^{\circ} \mathrm{C}$ in an orbital shaker. After 48 hours, $1 \mathrm{~mL}$ of the first growth was transferred to test tubes containing $9 \mathrm{~mL}$ of Brunner medium and incubated under the same conditions described above.

The SF defluorination was measured with a $\mathrm{F}^{-}$selective electrode (Thermo Electron Corporation) in 24-well plates containing $500 \mu \mathrm{L}$ of culture and $500 \mu \mathrm{L}$ of Total Ionic Strength Adjustment Buffer-TISAB (Diaminocyclohexane, sodium chloride, and glacial acetic acid, $\mathrm{pH}$ 5.5). The fluoride ion released by the microbial SF degradation was expressed in millimoles, the defluorination rate of $20 \mathrm{mmol} \mathrm{L}^{-1}$ corresponding to the release of $20 \mathrm{mmol} \mathrm{L}^{-1} \mathrm{~F}^{-}$.

Samples presenting SF defluorination were cultivated in serial dilutions from $10^{-1}$ to $10^{-9}$. To obtain pure colonies the highest dilution that presented SF defluorination was plated on Brunner agar (Brunner medium with agar 1\%) and incubated at $39^{\circ} \mathrm{C}$ for 72 hours. Subsequently, each colony was used to inoculate three test tubes containing $9 \mathrm{~mL}$ of Brunner medium, which were monitored for SF defluorination. Pseudomonas fluorescens (strain DSM 8341) was used as positive control for fluoroacetate dehalogenase activity, cultivated under the same conditions except that the incubation was at $28^{\circ} \mathrm{C}$ [24]. Nine $\mathrm{mL}$ of Brunner medium without bacteria were incubated under the same conditions to evaluate the sodium fluoroacetate degradation background.

2.3. 16S rRNA Gene Sequence Identification. Genus identification for bacteria displaying defluorination activity was done by polymerase chain reaction (PCR) amplification and sequencing of the $16 \mathrm{~S}$ rRNA gene. DNA extraction was performed with Brazol (LGC Biotechnology) according to the manufacturer's specifications. 16S rRNA gene was amplified in buffer containing $0.5 \mu \mathrm{M}$ of $27 \mathrm{f}$ and $1492 \mathrm{r}$ universal primers [25], $2 \mathrm{U}$ of Taq DNA polymerase, $0.2 \mathrm{mM}$ of dNTP and $100 \mathrm{ng}$ of DNA and ultrapure water to a final volume of $20 \mu \mathrm{L}$. In the negative control, the DNA volume was substituted by ultrapure water. The amplified products were applied into $1 \%$ agarose gel and submitted to electrophoresis. DNA was stained with ethidium bromide and bands visualized with an imaging system (UVP-Bioimaging Systems).

The sequencing reaction was performed with BigDye kit according to manufacturer's recommendations (Applied Biosystems) and the product sequenced in the Genetic Analyzer 3500 XL sequencer (Applied Biosystems).

2.4. Sequence Analysis and Phylogram. 16S rRNA gene sequences were assembled with the CAP3 Sequence Assembly Program (http://pbil.univ-lyon1.fr/cap3.php). DNA sequences were analyzed by basic local alignment search tool (BLAST) available on the website of the National Center for Biotechnology Information (NCB-http://www.ncbi.nlm .nih.gov/BLAST). Species identification was based on maximum score, identity and coverage values. The Greengenes database and workbench were used to corroborate species identification (http://greengenes.lbl.gov). The Bootstrap consensus tree was generated with MEGA5 software using the neighbor-joining statistical method (http://www.megasoftware.net/mega.php) [26].

\section{Results and Discussion}

The 16S rRNA gene sequences from the two fluoroacetate degrading isolates ECPB08 (JQ345720) and ECPB09 (JQ345721) were similar to the 16S rRNA genes from Pigmentiphaga and Ancylobacter species, respectively (Table 1). On the basis of score value alone, the $P$. kullae sequence was the most similar (score $=2237$ ) to ECPB08, although other $16 \mathrm{~S}$ rRNA sequences had the same coverage and identity parameter values. Similarly, the $16 \mathrm{~S}$ rRNA sequences from Ancylobacter vacuolatus and Ancylobacter sp. strain WPCB135 were the most similar (score 2388) to ECPB09, but the differences in alignment parameters for other Ancylobacter $16 \mathrm{~S}$ rRNA sequences were only marginal. Consequently, it was not possible to infer from the score values which species would be phylogenetically the closest to ECPB09 (JQ345721).

Comparative sequence analysis using global alignment confirmed that the isolates ECPB08 (JQ345720) and ECPB09 
TABLE 1: Local alignment results for fluoroacetate-degrading bacterial isolates $16 \mathrm{~S}$ rRNA sequences. Sequences were compared to those deposited at the National Center for Biotechnology Information using the regular BlastN algorithm available at http://www.ncbi.nlm.nih .gov/BLAST. Organisms with sequences similar to those of isolates ECPB08 (JQ345720) and ECPB09 (JQ345721) are listed on the second column. Values for the parameters total score, query coverage, and maximum identity are displayed in columns 3 to 5 . GenBank access codes are displayed in parentheses.

\begin{tabular}{|c|c|c|c|c|}
\hline Isolate (acc. no.) & Species/strain (accession no.) & Total score & Query coverage (\%) & Max identity (\%) \\
\hline \multirow{4}{*}{ ЕСРВ08 (JQ345720) } & Pigmentiphaga kullae strain K24 (NR_025112.1) & 2237 & 100 & 98 \\
\hline & Pigmentiphaga daeguensis strain K110 (NR_044082.1) & 2215 & 100 & 98 \\
\hline & Pigmentiphaga daeguensis strain NML080357 (JN585327.1) & 2197 & 100 & 97 \\
\hline & Pigmentiphaga litoralis strain JSM 061001 (NR_044530.1) & 2152 & 99 & 97 \\
\hline \multirow{8}{*}{ ECPB09 (JQ345721) } & Ancylobacter sp. WPCB135 (FJ006900.1) & 2388 & 99 & 99 \\
\hline & Ancylobacter vacuolatus strain DSM 1277 (NR_042794.1) & 2388 & 99 & 99 \\
\hline & Ancylobacter dichloromethanicus strain DM16 (EU589386.1) & 2387 & 99 & 99 \\
\hline & Ancylobacter polymorphus strain DSM 2457 (NR_042795.1) & 2372 & 99 & 99 \\
\hline & Ancylobacter rudongensis strain AS1.1761 (NR_029047.1) & 2370 & 99 & 99 \\
\hline & Ancylobacter polymorphus T10AII (GQ921957.1) & 2358 & 98 & 99 \\
\hline & Ancylobacter aquaticus (NR_044737.1) & 2351 & 99 & 98 \\
\hline & Ancylobacter oerskovii strain NS05 (NR_042655.1) & 2341 & 99 & 98 \\
\hline
\end{tabular}

(JQ345721) were phylogenetically closely related to the genera Pigmentiphaga and Ancylobacter, respectively (Figure 1). Indeed, the global alignment corroborates the taxonomic inference based on the $16 \mathrm{~S}$ rRNA local alignment results for ECPB08 (JQ345720), indicating that this isolate is closely related to P. kullae strain K24 (Figure 1(a)), and is supported by previous results on the taxonomy of this genus [27, 28]. Moreover, the global alignment allowed a better estimative of taxon position for ECPB09 (JQ345721), suggesting its close relationship with A. polymorphus (Figure 1(b)). Although the upper part of the tree in Figure 1(b) has low bootstrap values, the whole dendrogram is consistent with the results presented by Firsova et al. [29] for the genus Ancylobacter.

The genus Pigmentiphaga was initially proposed by Blümel et al. [30] with Pigmentiphaga kullae (strain K24) as its unique specie, which degrades xenobiotic compounds. In 2007, Yoon et al. [31] described a new member of the genus, Pigmentiphaga daeguensis (strain K110T), isolated from wastewater collected from a dye works in Korea. Later, Chen et al. [27] and Lee et al. [28] isolated Pigmentiphaga litoralis (strain JSM 061001) and P. soli from a tidal flat sample in the South China Sea and from soil in South Korea, respectively.

Raj and Maloy [32] proposed the replacement of the genus name Microcyclus by Ancylobacter, with a single species, $A$. aquaticus [33]. Since then, five new species have been described, the latest being Ancylobacter dichloromethanicus (strain DM16), isolated from contaminated soil [29]. This species uses dichloromethane, methanol, formate, and formaldehyde polycarbonate compounds as carbon and energy sources. Enzymatic analysis showed that it contains a GSH-dependent dichloromethane dehalogenase.

Both ECPB08 (JQ345720) and ECPB09 (JQ345721) grew in culture medium containing SF as the sole carbon source. These bacteria displayed SF degradation activity, releasing $20 \mathrm{mmol} \mathrm{L}^{-1}$ of fluoride ion after 32 hours of incubation in
Brunner medium with $20 \mathrm{mmol} \mathrm{L}^{-1}$ of SF (Figure 2). These results are similar to those reported by Davis et al. [34] for Burkholderia sp. The Pseudomonas fluorescens control strain (DSM 8341) reached the same level of defluorination, and there was no release of fluoride ions when the Brunner medium was incubated without bacteria, due to the stability of the strong carbon-fluorine bond in the fluoroacetate [17]. There are no previous reports of fluoroacetate dehalogenase activity for any Pigmentiphaga or Ancylobacter species.

The defluorination ability of both isolates can be due to the expression of a fluoroacetate dehalogenase gene or to another unspecific dehalogenase. Although for Pigmentiphaga no dehalogenase gene has yet been described, a dichloromethane dehalogenase sequence from $A$. dichloromethanicus is deposited in GenBank [29]. Liu et al. [35] confirmed that fluoroacetate dehalogenase degrades other halogenated compounds such as chloroacetate, bromoacetate, iodoacetate, and dichloroacetate, by a crossadaptation mechanism [36]. Similar results were obtained by Donnelly and Murphy [24] who found a fluoroacetate dehalogenase able to degrade chloroacetate, bromoacetate, and ethyl fluoroacetate. Alternatively, sodium fluoroacetate was defluorinated by L-2 haloacid dehalogenase [18].

Sodium fluoroacetate degrading bacteria, mostly Bacillus and Flavobacterium species, were isolated from soil in Australia, even in the absence of sodium fluoroacetate in the environment [37]. In this study, two Pigmentiphaga and Ancylobacter species were isolated from goat rumen, although the animals were not fed plants that produce this component. This finding suggests that the fluoroacetate dehalogenase gene is rather ubiquitous and that its expression may represent a selective advantage for microorganism, possible due to the ability of the enzyme to degrade other related compounds, as mentioned before.

On the other hand, it has been reported that animals grazing in areas where Mascagnia rigida is present are more resistant to poisoning than those kept in areas without these 


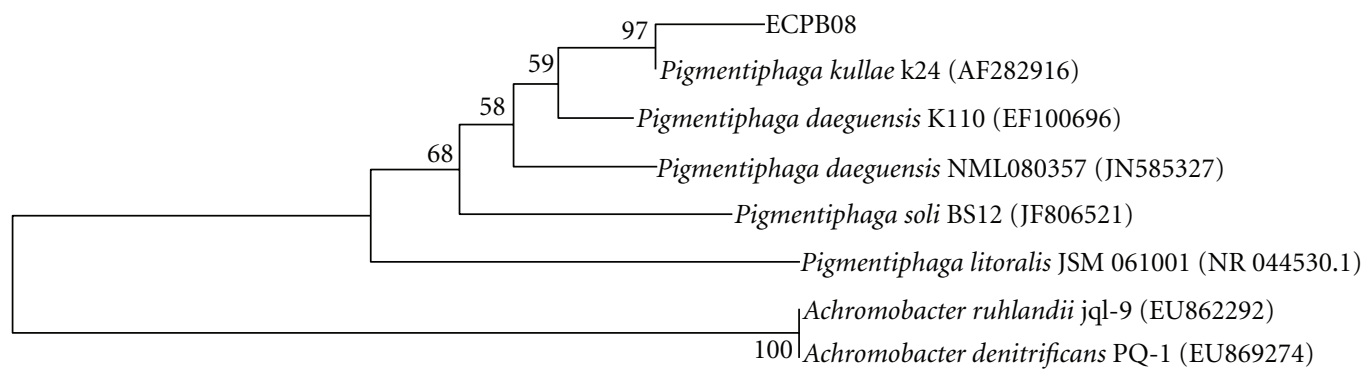

$\longmapsto 002$

(a)

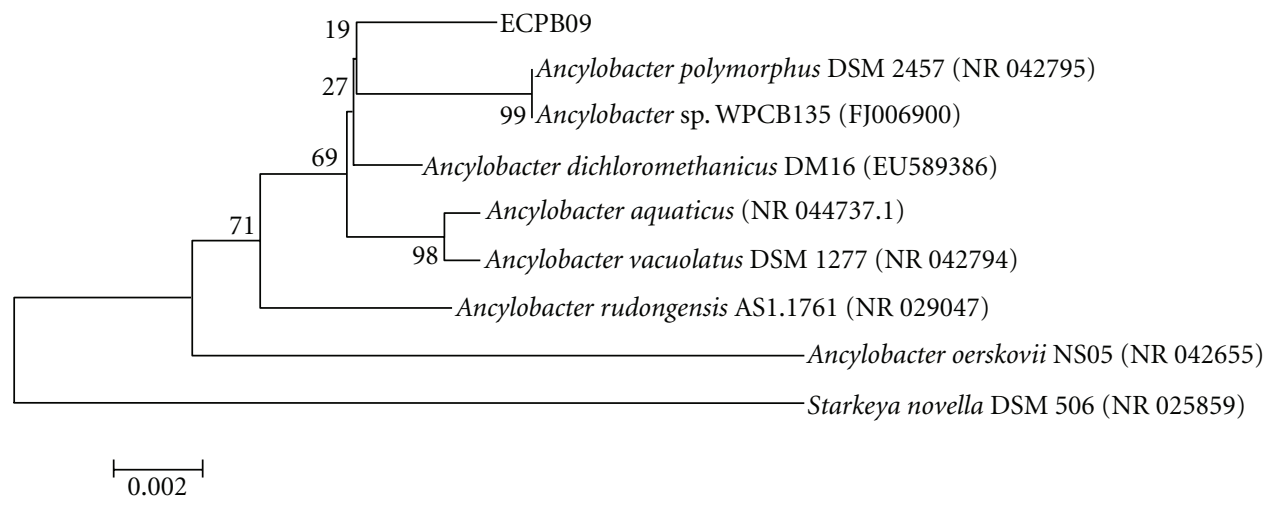

(b)

FIgure 1: Phylogenetic tree based on 16S rRNA sequences by Maximum Parsimony analysis. ECPB08 (JQ345720) and ECPB09 (JQ345721) are the codes for the isolates. In parentheses are the GenBank codes. The relationship between ECPB08 (JQ345720) (a), ECPB09 (JQ345721) (b) related taxa, and the outgroups Achromobacter ruhlandii, A. denitrificans, and Starkeya novella is shown. The bootstrap consensus tree inferred from 1000 replicates is taken to represent the evolutionary history of the taxa analyzed. Scale of 0.002: evolutionary distance.

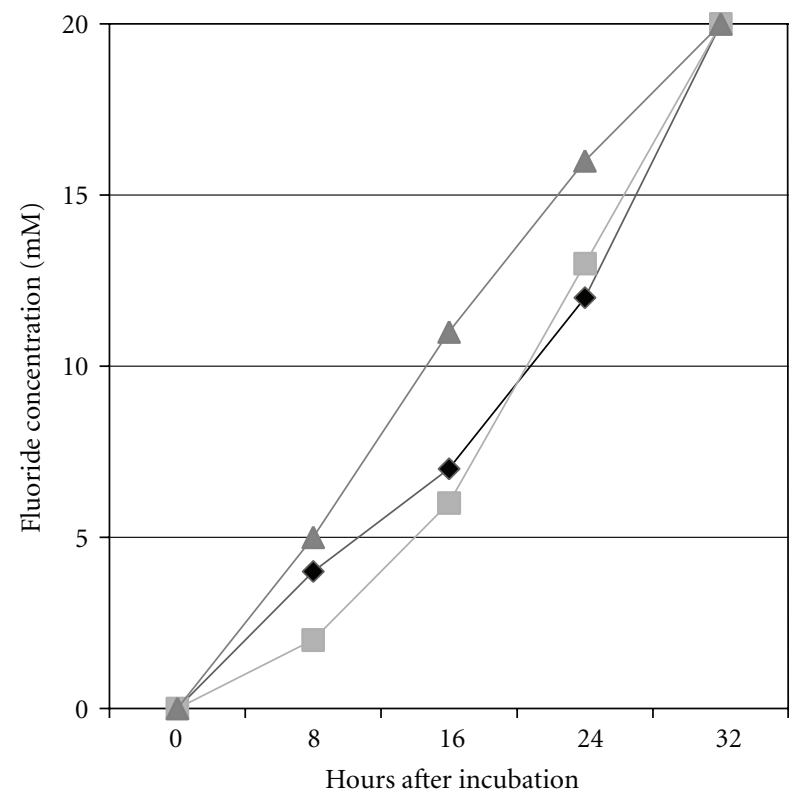

Figure 2: Sodium fluoroacetate degradation rate by bacteria isolated from caprine rumen. Isolate ECPB08 (light grey square), isolate ECPB09 (black rhombus), and P. fluorescens (dark grey triangle, positive control). plants [6]. Recent results of our research group demonstrated that resistance to $M$. rigida poisoning can be induced by the administration of repeated low nontoxic doses of the plant or by transfaunation of rumen fauna from resistant to susceptible animals (unpublished data). These results suggest that either changes in rumen microflora or sustained high expression levels of the SF dehalogenase gene from the endogenous rumen microbiota are responsible for this tolerance.

Control measures to prevent plant intoxication, including use of fences, herbicides, or other methods of eliminating poisonous plants, have been unsuccessful to avoid poisoning by fluoroacetate containing plants in Brazil [38]. An alternative way would be the microbial detoxification of plants by inoculation of fluoroacetate degrading bacteria into the rumen. This strategy was used by Gregg et al. [39] who inoculated in the rumen a genetically modified strain of Butyrivibrio fibrisolvens with a gene encoding fluoroacetate dehalogenase from Moraxella species, which was efficient to prevent fluoroacetate poisoning in sheep. In an alternative approach, the two isolates, Pigmentiphaga sp. and Ancylobacter sp. are candidates to be used in colonizing the rumen to avoid intoxication by fluoroacetate containing plants. 


\section{Acknowledgment}

This work was supported by the INCT for the control of plant poisonings, Grant no.: 573534/2008-0.

\section{References}

[1] A. Gava, J. Cristani, J. V. Branco, D. S. Neves, A. J. Mondadori, and R. S. Sousa, "Sudden death in cattle by Mascagnia sp (Malpighiaceae) in the State of Santa Catarina, Brazil," Pesquisa Veterinaria Brasileira, vol. 18, no. 1, pp. 16-20, 1998.

[2] M. A. Helayel, T. N. França, J. N. Seixas, V. A. Nogueira, S. A. Caldas, and P. V. Peixoto, "Sudden death in cattle caused by ingestion of Pseudocalymma elegans (Bignoniaceae) in the county of Rio Bonito, Rio de Janeiro," Pesquisa Veterinaria Brasileira, vol. 29, no. 7, pp. 498-508, 2009.

[3] R. M. T. Medeiros, S. A. Geraldo Neto, R. C. Barbosa, E. F. Lima, and F. Riet-Correa, "Sudden bovine death from Mascagnia rigida in Northeastern Brazil," Veterinary and Human Toxicology, vol. 44, no. 5, pp. 286-288, 2002.

[4] S. P. Pavarini, M. P. Soares, P. M. Bandarra et al., "Sudden death in cattle due to the consumption of Amorimia exotropica (Malpighiaceae) in Rio Grande do Sul, Brazil," Pesquisa Veterinaria Brasileira, vol. 31, no. 4, pp. 291-296, 2011.

[5] B. Soto-Blanco, M. Haraguchi, J. A. Silva, and Górniak, "Intoxicação natural de caprinos e ovinos por Palicourea marcgravii St. Hil. (Rubiaceae)," Caatinga, no. 1, pp. 52-56, 2004.

[6] I. P. Silva, R. A. Lira, R. R. Barbosa, J. S. Batista, and B. SotoBlanco, "Intoxicação natural pelas folhas de Mascagnia rigida (Malpighiaceae) em ovinos," Arquivos do Instituto Biologico, vol. 75, no. 2, pp. 229-233, 2008.

[7] S. V. Schons, T. L. de Mello, F. Riet-Correa, and A. L. Schild, "Poisoning by Amorimia (Mascagnia) sepium in sheep in Northern Brazil," Toxicon, vol. 57, no. 5, pp. 781-786, 2011.

[8] C. H. Tokarnia, J. Döbereiner, and P. V. Peixoto, Plantas Tóxicas do Brasil, Editora Helianthus, Rio de Janeiro, Brazil, 2000.

[9] J. S. Vasconcelos, F. Riet-Correa, A. F. M. Dantas et al., "Poisoning by Mascagnia rigida (Malpighiaceae) in sheep and goats," Pesquisa Veterinaria Brasileira, vol. 28, no. 10, pp. 521526, 2008.

[10] J. S. Vasconcelos, F. Riet-Correa, A. F. M. Dantas, R. M. T. Medeiros, and A. J. A. Dantas, "Sudden deaths caused by Palicourea aeneofusca (Rubiaceae) and Mascagnia rigida (Malpighiaceae) in cattle in the Zona da Mata of Paraíba," Pesquisa Veterinaria Brasileira, vol. 28, no. 10, pp. 457-460, 2008.

[11] C. H. Tokarnia, P. V. Peixoto, and J. Dobereiner, "Poisonous plants affecting heart funtions of cattle in Brazil," Pesquisa Agropecuária Brasileira, vol. 10, pp. 1-10, 1990.

[12] M. M. de Oliveira, "Chromatographic isolation of monofluoroacetic acid from Palicourea marcgravii St. Hil," Experientia, vol. 19, no. 11, pp. 586-587, 1963.

[13] H. C. Krebs, W. Kemmerling, and G. Habermehl, "Qualitative and quantitative determination of fluoroacetic acid in Arrabidea bilabiata and Palicourea marcgravii by 19F-NMR spectroscopy," Toxicon, vol. 32, no. 8, pp. 909-913, 1994.

[14] L. C. Cunha, S. L. Gorniak, M. Haraguchi, F. Riet-Correa, F. G. Xavier, and J. C. Florio, "Palicourea marcgravii e Mascagnia rigida: um estudo por cromatografia em camada delgada (CCD)," in Proceedings of the II Simpósio de Pós-Graduação and XV Semana Científica, Prof. Dr. Benjamin Eurico Malucelli, São Paulo, Brazil, 2006.
[15] F. Riet-Correa and M. C. Méndez, "Intoxicações por plantas e micotoxinas," in Doenças de Ruminantes e Eqüídeos, F. RietCorrea, A. L. Schild, R. A. A. Lemos, and J. R. J. Borges, Eds., vol. 2, Editora Pallotti, Santa Maria, RS, Brasil, 2007.

[16] P. A. Mayes, "O ciclo do ácido cítrico: o catabolismo da AcetilcoA," in Harper: Bioquímica, K. R. Murray, Ed., pp. 182-189, Atheneu, São Paulo, Brazil, 9th edition, 2002.

[17] S. Fetzner and F. Lingens, "Bacterial dehalogenases: biochemistry, genetics, and biotechnological applications," Microbiological Reviews, vol. 58, no. 4, pp. 641-685, 1994.

[18] T. Kurihara, T. Yamauchi, S. Ichiyama, H. Takahata, and N. Esaki, "Purification, characterization, and gene cloning of a novel fluoroacetate dehalogenase from Burkholderia sp. FA1," Journal of Molecular Catalysis B, vol. 23, no. 2-6, pp. 347-355, 2003.

[19] W. Y. Chan, M. Wong, J. Guthrie et al., "Sequence- and activity-based screening of microbial genomes for novel dehalogenases," Microbial Biotechnology, vol. 3, no. 1, pp. 107$120,2010$.

[20] L. E. Twigg and L. V. Socha, "Defluorination of sodium monofluoroacetate by soil microorganisms from central Australia," Soil Biology and Biochemistry, vol. 33, no. 2, pp. 227234, 2001.

[21] E. K. A. Camboim, M. Z. Tadra-Sfeir, E. M. Souza et al., "Defluorination of sodium fluoroacetate by bacteria from soil and plants in Brazil," The Scientific World Journal, vol. 2012, Article ID 149893, 5 pages, 2012.

[22] C. Davis, Investigations on the microbial degradation of fluoracetate [Ph.D. thesis], School of Chemistry and Molecular Bioscience. The University of Queensland, Australia, 2011.

[23] L. E. X. Leong, S. E. Denman, C. K. Davis, T. Huber, and C. S. McSweeney, "Peptide utilization of the novel fluoracetatedegrading ruminal bacterium," Proceedings of the Australian Society of Animal Production, vol. 28, p. 64, 2010.

[24] C. Donnelly and C. D. Murphy, "Purification and properties of fluoroacetate dehalogenase from Pseudomonas fluorescens DSM 8341," Biotechnology Letters, vol. 31, no. 2, pp. 245-250, 2009.

[25] W. G. Weisburg, S. M. Barns, D. A. Pelletier, and D. J. Lane, "16S ribosomal DNA amplification for phylogenetic study," Journal of Bacteriology, vol. 173, no. 2, pp. 697-703, 1991.

[26] K. Tamura, D. Peterson, N. Peterson, G. Stecher, M. Nei, and S. Kumar, "MEGA5: molecular evolutionary genetics analysis using maximum likelihood, evolutionary distance, and maximum parsimony methods," Molecular Biology and Evolution, vol. 28, no. 10, pp. 2731-2739, 2011.

[27] Y. G. Chen, Y. Q. Zhang, K. Huang et al., "Pigmentiphaga litoralis sp. nov., a facultatively anaerobic bacterium isolated from a tidal flat sediment," International Journal of Systematic and Evolutionary Microbiology, vol. 59, no. 3, pp. 521-525, 2009.

[28] J. J. Lee, S. Srinivasan, and M. K. Kim, "Pigmentiphaga soli sp. nov., a bacterium isolated from soil," J. Microbiol, vol. 49, no. 5, pp. 857-861, 2011.

[29] J. Firsova, N. Doronina, E. Lang, C. Spröer, S. Vuilleumier, and Y. Trotsenko, "Ancylobacter dichloromethanicus sp. nov.a new aerobic facultatively methylotrophic bacterium utilizing dichloromethane," Systematic and Applied Microbiology, vol. 32, no. 4, pp. 227-232, 2009.

[30] S. Blümel, B. Mark, H. J. Busse, P. Kämpfer, and A. Stolz, "Pigmentiphaga kullae gen. nov., sp. nov., a novel member of the family Alcaligenaceae with the ability to decolorize azo dyes aerobically," International Journal of Systematic and Evolutionary Microbiology, vol. 51, no. 5, pp. 1867-1871, 2001. 
[31] J. H. Yoon, S. J. Kang, W. Kim, and T. K. Oh, "Pigmentiphaga daeguensis sp. nov., isolated from wastewater of a dye works, and emended description of the genus Pigmentiphaga," International Journal of Systematic and Evolutionary Microbiology, vol. 57, no. 6, pp. 1188-1191, 2007.

[32] H. D. Raj and S. R. Maloy, "Family Spirosomaceae: gramnegative ring-forming aerobic bacteria," Critical Reviews in Microbiology, vol. 17, no. 5, pp. 329-364, 1990.

[33] J. Orskov, "Beschreibung eines neuen Microben, Microcyclus aquaticus, mit eigentiimlicher Morphologie," Zentralblatt fur Bakteriologie, Parasitenkunde, Infektionskrankheiten und Hygiene, vol. 107, pp. 180-184, 1923.

[34] C. K. Davis, S. E. Denman, L. I. Sly, and C. S. McSweeney, "Development of a colorimetric colony-screening assay for detection of defluorination by micro-organisms," Applied Microbiology, vol. 53, no. 4, pp. 417-423, 2011.

[35] J. Q. Liu, T. Kurihara, S. Ichiyama et al., "Reaction mechanism of fluoroacetate dehalogenase from Moraxella sp. B," Journal of Biological Chemistry, vol. 273, no. 47, pp. 30897-30902, 1998.

[36] I. S. Melo and J. L. Azevedo, "Como isolar microrganismos degradadores de moléculas xenobióticas," in Microbiologia Ambiental, I. S. Melo and L. J. Azevedo, Eds., pp. 167-183, EMBRAPA-CNPMA, Jaguariuna, Brazil, 1997.

[37] D. H. Wong, W. E. Kirkpatrick, D. R. King, and J. E. Kinnear, "Defluorination of sodium monofluoroacetate (1080) by microorganisms isolated from western Australian soils," Soil Biology and Biochemistry, vol. 24, no. 9, pp. 833-838, 1992.

[38] F. Riet-Correa and R. M. T. Medeiros, "Intoxicações por plantas em ruminantes no Brasil e no Uruguai: importância econômica, controle e riscos para a saúde pública," Pesquisa Veterinaria Brasileira, vol. 21, no. 1, pp. 38-42, 2001.

[39] K. Gregg, B. Hamdorf, K. Henderson, J. Kopecny, and C. Wong, "Genetically modified ruminal bacteria protect sheep from fluoroacetate poisoning," Applied and Environmental Microbiology, vol. 64, no. 9, pp. 3496-3498, 1998. 

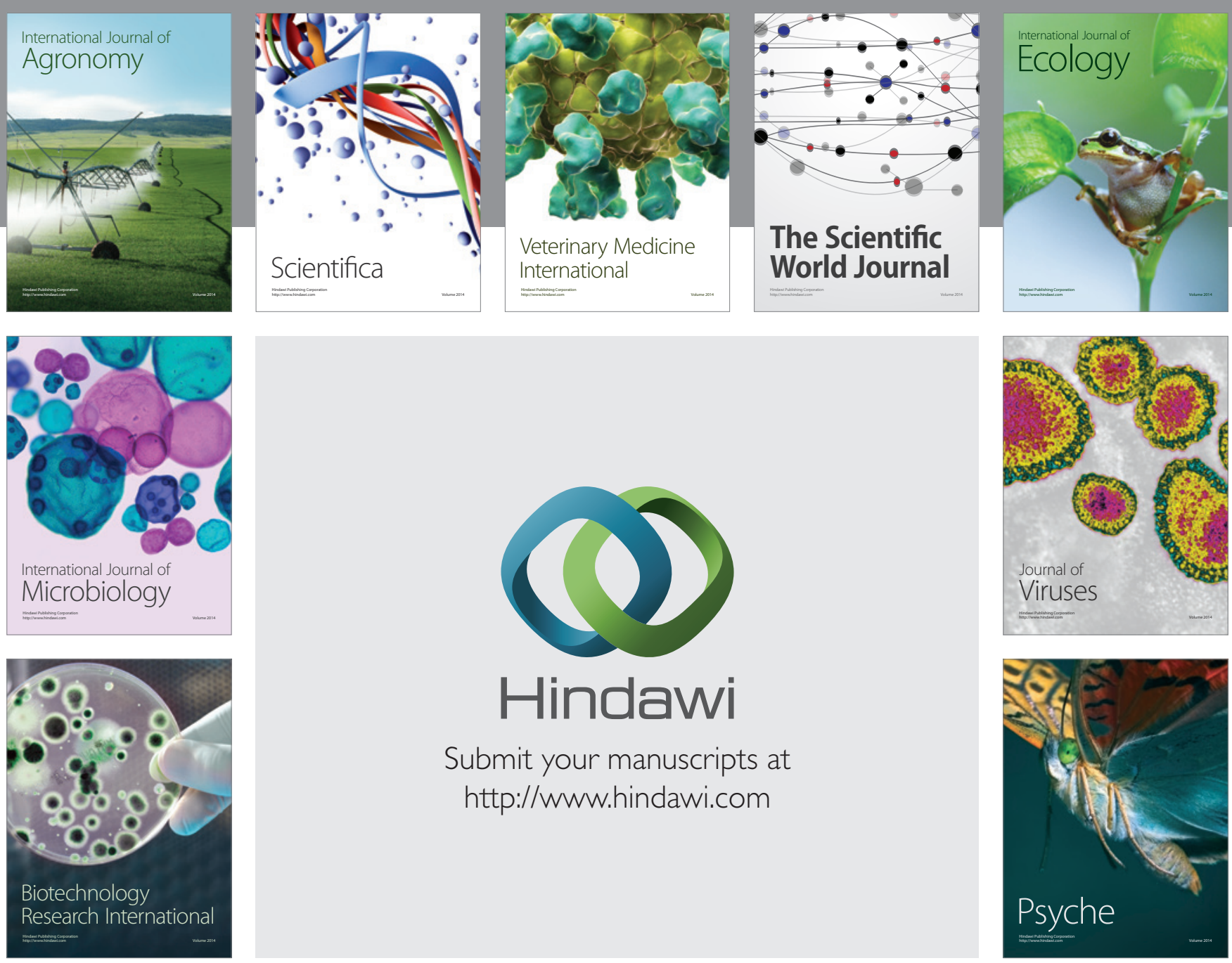

Submit your manuscripts at

http://www.hindawi.com
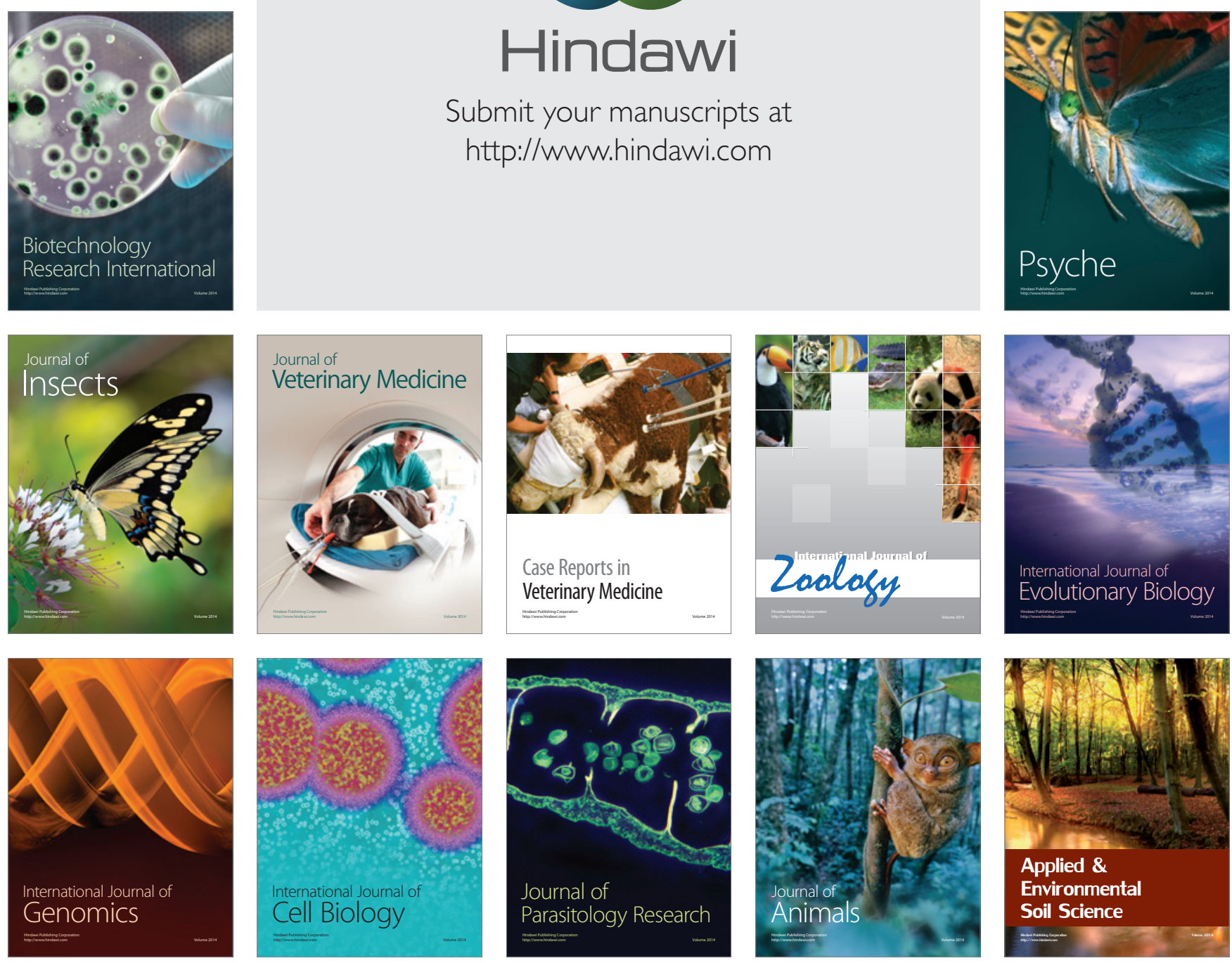